
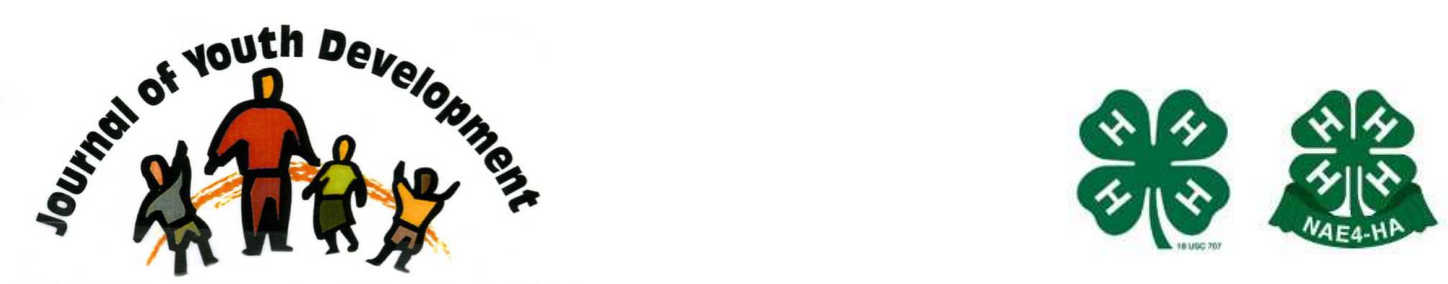

Bridging Research \& Practice

\title{
Generating Youth Interest in Science Careers Through 4-H Health Science Explorations
}

\author{
Thomas Hutson \\ 4-H Youth Development \\ University of Maryland Extension - Talbot County \\ Easton, MD \\ thutson@umd.edu \\ Sharon Pahlman \\ 4-H Youth Development \\ University of Maryland Extension - Caroline County \\ Denton, MD \\ spahlman@umd.edu
}




\title{
JOURNAL OF YOUTH DEVELOPMENT \\ bridging research and practice

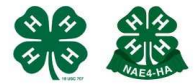

Volume 7, Number 2, Summer 2012

Article 120702PA003

\section{Generating Youth Interest in Science Careers Through 4-H Health Science Explorations}

\author{
Thomas Hutson and Sharon Pahlman \\ University of Maryland Extension
}

\begin{abstract}
Health Science Explorations is a Maryland 4-H Program for youth ages ten and older. Hospital-based multi-day summer sessions and clubs that meet regularly, enable youth to interact with health care professionals in authentic medical settings. The program introduces youth to local health career opportunities, fosters science literacy and interest in science careers, and teaches healthy lifestyle practices. The authors share strategies to guide other educators through the process of developing their own science career exploration programs.
\end{abstract}

\section{Introduction}

For more than one hundred years, 4-H Youth Development educators and volunteers have been helping America's young people develop skills for success in adult life. One of the strengths of Extension's 4-H programs is their ability to change with the times and address emerging community needs (CSREES, 2011). National 4-H Mission Mandates emphasize the importance of providing science, healthy lifestyles, and citizenship opportunities for youth across the country. State and local 4-H programs work to incorporate national goals as they tailor programs to address local needs and interests.

In addition to national 4-H mandates, the weak U.S. economy has brought to light the need for improved youth workforce preparation. The country faces a future of intense global competition in science and technology fields, but startling under-enrollment in college science majors is contributing to a shortage of U.S. scientists. In fact, only 18 percent of U.S. high school seniors are proficient in science (Grigg, Lauko, \& Brockway, 2006) and a mere 5 percent of U.S. college graduates earn science, engineering, or technology degrees as compared to 66 percent in Japan and 59 percent in China (4-H Science, 2011). 
To address increasing demand for science and technology professionals, Maryland 4-H science education programs are working to help ensure global competitiveness by preparing the next generation of U.S. science, engineering, and technology leaders.

\section{Program Description}

4-H Health Science Explorations, currently offered to youth from the rural counties on Maryland's Eastern Shore, is a program that addresses the dual needs for youth science education and workforce development. Health care is the number one employment sector in Talbot County and a top employer of residents from neighboring Caroline and Dorchester Counties (Sage Policy Group, 2007), but the area experiences periodic shortages in adults qualified to fill local health industry jobs. The authors are University of Maryland Extension 4-H educators who design learning experiences that introduce youth to a variety of health science career opportunities. A long-term goal of these efforts is to increase the number of local residents who are prepared to fill health care vacancies.

The Health Science Explorations program is a collaborative effort among three county 4-H programs, Shore Health System (the local hospital network), and Eastern Shore Area Health Education Center (a private non-profit with an educational mission). Innovative learning experiences allow youth to explore health science careers through venues including multi-day summer hospital immersion experiences and clubs based at two local hospitals.

The program's hands-on health science career activities are designed to accomplish three major goals:

- Familiarize youth with health career opportunities through interaction with medical professionals.

- Improve science literacy and generate youth interest in pursuing health science careers.

- Promote two National 4-H Mission Mandates: 4-H Science and Healthy Lifestyles.

\section{Program Design}

Unlike some career programs in which guest speakers present "canned" programs at schools, this program brings youth together with medical professionals in authentic medical settings. As a result, youth gain firsthand experience of the working conditions, working environment, and specialized equipment associated with a variety of health careers.

Each summer, the 4-H educators meet with community partners, select a health care theme (heart and lungs, muscles and bones, etc.), and jointly plan a three-day summer program based at a local hospital. Youth are recruited through print and online newsletters, press releases, flyers, and word of mouth. The program is open to all youth ages ten and up from Maryland's rural Eastern Shore counties. Due to hospital department space limitations, summer enrollment is capped at twenty participants.

Summer program experiences include:

- Pre-assessment to determine familiarity with and interest in selected health careers

- Tours of hospital departments and interaction with medical professionals from each department

- Participation in experiential learning activities designed and taught by 4-H educators and volunteers

- Demonstrations and opportunities to work with medical equipment including electrocardiograph machines, robotic patient simulators, radiology devices, laparoscopic 
surgery simulators, patient lift equipment, first aid supplies, and physical therapy/fitness equipment,

- Exploration of healthy lifestyle practices, dietary recommendations from ChooseMyPlate.gov (CSREES, 2011), and selection of healthy food choices

- Post-assessment and summary activities to provide closure

Long-term, positive interaction with caring adults is a crucial component of 4-H youth development (Lerner, Lerner, Phelps, \& Colleagues, 2008). Consequently, the educators and volunteers have implemented evening health science clubs that meet a minimum of eight times per year at local hospitals and offer additional opportunities for learning from health care professionals. Holding club meetings in a hospital setting adds a sense of legitimacy to the program and increases convenience for guest presenters, many of whom are hospital employees. The educators plan to expand the program's geographic range by setting up similar learning experiences in two additional Eastern Shore counties. They have also applied to teach a summer health science program at the local community college.

\section{Program Outcomes and Impacts}

Prior to each summer program, youth participants completed an IRB-approved pre-assessment questionnaire. A single "check all that apply" item measured self-reported familiarity with selected health careers to be explored during the program. At the conclusion of each summer program, youth participants completed an IRB-approved post-assessment questionnaire that duplicated the pre-assessment item and included four additional items. One "check all that apply" item assessed knowledge of educational requirements for each career. Two "yes/no" items assessed interest in pursuing health science careers and interest in attending future programs of this type.

The data tables below summarize pre-assessment (Table 1) and post-assessment (Table 2) data. In both tables, $\mathrm{N}=$ number of youth who attended all sessions and completed both assessments. (Data for youth who missed learning sessions and/or one of the assessments are not included.) Results are reported as mean and percentage.

Table 1

Three-day summer session evaluation data from 2010 and 2011 $\mathrm{N}=$ number who attended all days and completed pre- and post-evaluations

\begin{tabular}{|c|c|c|c|c|c|c|}
\hline PRE-ASSESSMENT & Sum & 2010 & $\begin{array}{r}\text { Sum } \\
\text { RET } \\
\text { Par }\end{array}$ & $\begin{array}{l}2011 \\
\text { ING } \\
\text { ants }\end{array}$ & $\begin{array}{l}\text { Sum } \\
\qquad \mathrm{Pa}\end{array}$ & $\begin{array}{l}2011 \\
\text { ants } \\
3\end{array}$ \\
\hline $\begin{array}{l}\text { 1. Which of these health science } \\
\text { careers were you familiar with? } \\
\text { Check all that apply. } \\
\text { (Note: } 11 \text { careers were explored in } 2010 \\
\text { and } 9 \text { careers were explored in 2011) }\end{array}$ & 4.38 & $39 \%$ & 7.86 & $87 \%$ & 4.13 & $46 \%$ \\
\hline
\end{tabular}


Table 2

Analysis of 2010 and 2011 Health Science Explorations summer session post-assessment data.

\begin{tabular}{|c|c|c|c|c|c|c|}
\hline \multirow{2}{*}{\begin{tabular}{|l|} 
POST-ASSESSMENT \\
1. Which of these health science \\
careers are you familiar with? \\
Check all that apply. \\
(Note: 11 careers were explored in 2010 \\
and 9 careers were explored in 2011.)
\end{tabular}} & \multicolumn{2}{|c|}{$\begin{array}{l}\text { Summer } 2010 \\
\qquad N=16\end{array}$} & \multicolumn{2}{|c|}{$\begin{array}{l}\text { Summer } 2011 \\
\text { RETURNING } \\
\begin{array}{c}\text { Participants } \\
\mathrm{N}=7\end{array}\end{array}$} & \multicolumn{2}{|c|}{$\begin{array}{l}\text { Summer } 2011 \\
\text { NEW } \\
\text { participants } \\
\mathrm{N}=8\end{array}$} \\
\hline & 9.75 & $87 \%$ & 7.75 & $86 \%$ & 9.00 & $100 \%$ \\
\hline $\begin{array}{l}\text { 2. Which of these health science } \\
\text { careers require additional education } \\
\text { after high school? } \\
\text { Check all that apply. }\end{array}$ & 8.88 & $81 \%$ & 7.71 & $86 \%$ & 9.00 & $100 \%$ \\
\hline $\begin{array}{l}\text { 3. Did this program make you more } \\
\text { interested in working in a health } \\
\text { science career when you grow up? } \\
\text { Yes/No }\end{array}$ & 14.00 & $88 \%$ & 7.86 & $87 \%$ & 6.00 & $75 \%$ \\
\hline $\begin{array}{l}\text { 4. Are you interested in attending } \\
\text { more health science career } \\
\text { programs like this one? } \\
\text { Yes/No }\end{array}$ & 14.00 & $88 \%$ & 7.00 & $100 \%$ & 7.00 & $88 \%$ \\
\hline
\end{tabular}

Summer program outcomes include:

- A total of 37 youth who participated in the two summer sessions.

- An increase in 2010 mean familiarity with eleven careers from 39\% (pre) to $87 \%$ (post).

- An increase in 2011 mean familiarity with nine careers from $46 \%$ (pre) to $100 \%$ (post).

- One-year follow-up retention of career familiarity ( $87 \%$ in 2010 compared to $86 \%$ in 2011) among returning participants.

- A high level of understanding that postsecondary education is required for health careers.

- A large increase of interest in pursuing health science careers after high school.

- A high level of interest in attending future health science career programs.

Health science club outcomes include:

- Participation by 41 youth in ongoing health science club activities.

- Support in the form of membership scholarships to $12 \%$ of participants based on expressed financial need.

- Interaction with professionals from health care fields including nurse midwife, EMT/paramedic, first aid instructor, stress management specialist, nutritionist, medical lab technician, radiology technologist, dentist, and optometrist.

- Training for 18 youth in first aid and CPR certification. (Free training is not readily available to youth in the local area.)

- Opportunities for high school students to participate in health career job shadowing. 


\section{Science Career Exploration Program Strategies for Educators}

Based on two years of experience coordinating Health Science Explorations, the authors suggest several strategies for educators who wish to develop their own science career exploration programs.

$\checkmark$ Choose a major science or technology sector in your local area. Check with your local economic development office to find a list of the top employment sectors in your area, and select one or more science-based sectors from the list.

$\checkmark$ Identify potential partners and gain buy-in. Familiarize partners with the mission of your youth development organization. Emphasize that your goal is to interest youth in science careers and help produce qualified applicants for future science job vacancies in the local area. Finally, explain that the collaboration will result in positive publicity for all parties involved.

$\checkmark$ Search for an additional partner agency with an educational mission. After you have selected your primary partners, solicit additional expertise by identifying a partner organization whose mission is education related to the chosen career sector. This partner can provide valuable educational materials, presenters, and resources.

$\checkmark$ Recruit knowledgeable, engaging presenters. Identify professionals who have good interpersonal skills. Career information will be more accurate and credible if it comes from people who actually work in the field they are describing. Many businesses have public relations personnel or educational outreach specialists who are skilled at identifying youthfriendly presenters. The best presenters immerse youth in activities or simulations that help them get a feel for each career.

$\checkmark$ Ensure that learning activities are fun and interesting. Describe the desired format of instruction to each presenter (hands-on, interactive, exciting, related to real life) and help presenters identify age-appropriate activities. Despite their best intentions, some presenters who are not familiar with youth audiences encounter difficulty offering hands-on activities. An essential role of youth development professionals is advance preparation of activities that can supplement professional presentations when necessary.

$\checkmark$ Be sure that presenters cover the requested material. It is helpful to provide presenters with a list of topics (educational requirements, salary, job duties, etc.) ahead of time. Another option is to assign youth the task of asking each presenter specific questions during the presentations to ensure that topics are covered.

$\checkmark$ Plan the program collaboratively. Work with your partners and jointly develop a schedule. A typical program might involve visiting several departments of one large business or a series of visits to several related businesses. Build in time for youth to share skills they have learned or knowledge of careers they have researched. This is a nonthreatening public speaking opportunity for youth and a form of informal assessment.

$\checkmark$ Develop appropriate evaluations. Write the questions in advance, and make them simple and youth-friendly. Structure evaluations to collect useful data. Be sure the questions match the information to be learned. Consult with an assessment specialist for assistance. 
$\checkmark$ Market the program and enroll youth. Promotional materials should include the purpose of the program, a detailed program schedule (youth are more likely to sign up if they know exactly what they will be doing), program costs and sign-up procedures, Affirmative Action disclaimers, and any other relevant information. Advertise in as many venues as possible. Establish a reasonable maximum group size based on physical constraints of program facilities.

$\checkmark$ Conduct the program! Emphasize safety first and quality learning activities over those that lack educational value. To ensure safety and supervision, recruit sufficient adult volunteers. Supplement the sessions with experts by adding experiential activities led by 4-H educators and partners.

$\checkmark$ Be flexible. Be prepared for last-minute schedule changes and unavoidable delays. Have a set of back-up activities for youth to complete in the event that a presenter doesn't show. Some presenters need only fifteen minutes, and some need ninety minutes.

$\checkmark$ Evaluate the program and make revisions. Evaluate the program and report your findings to collaborators (they are interested in the results too!). Use feedback to make modifications that improve the program.

$\checkmark \quad$ Keep youth involved even after a finite program ends. Offer ongoing learning opportunities for participants. Encourage participants to join a local 4-H clubs that will keep them involved in the youth development experience.

\section{References}

4-H Science. (2011). Retrieved from http://www.4-h.org/youth-development-programs/4-hscience-programs/

CSREES About Us: Extension. (2011). Retrieved from USDA National Institute for Food and Agriculture website, http://www.csrees.usda.gov/qlinks/extension.html

Grigg, W., Lauko, M., \& Brockway, D. (2006). The nation's report card: Science 2005. Retrieved from the National Center for Education Statistics website. http://nces.ed.gov/nationsreportcard/pubs/ main2005/2006466.asp

Lerner, R.M., Lerner, J., Phelps, E., \& Colleagues. (2008). The 4-H study of positive youth development. Retrieved from the Tufts University Institute for Applied Research in Youth Development website: http://ase.tufts.edu/iaryd/documents/4HStudyFindings2008.pdf

Sage Policy Group, Inc. (October, 2007). A Strategic plan for the potential relocation of the Memorial Hospital at Easton. Retrieved from Talbot County Government Department of Economic Development.

(C) Copyright of Journal of Youth Development Bridging Research and Practice. Content may not be copied or emailed to multiple sites or posted to a listserv without copyright holder's express written permission. However, users may print, download or email articles for individual use. 